\title{
Improvement of Billet Rolling Yield by Press Preforming of Strand Cast Bloom*
}

\section{Introduction}

This paper describes the development and the installation of the bloom preforming press to improve billet rolling yield.

As is well known, the main cause of yield loss in billet rolling is crop loss due to fish tail and overlap.

The $3000 \mathrm{tf}$ preforming press was developed and installed at No. 2 Blooming Mill in Wakayama Steel Works of Sumitomo Metal Industries, Ltd. (Table 1.)
This press optimizes the shape of leading and tail ends of strand cast bloom prior to rolling in order to minimize the fish tail.

\section{The Optimum Preforming Conditions}

The optimum amount of forming $(\Delta W)$, position $(S)$, and die radius $(R)$ for each billet size were studied by the experiment at the Technical Research Laboratories.

Figure 1 shows the cast bloom

Table 1. Specifications of cast bloom preforming press.

\begin{tabular}{l|c}
\hline \multicolumn{1}{c|}{ Item } & \multicolumn{1}{c}{ Specification } \\
\hline Type & $\begin{array}{c}3000 \mathrm{tf} \text { hydraulic pressure forging press } \\
\text { (Horizontal type) } \\
3000 \mathrm{tf}\left(\text { at hydraulic pressure } 181.7 \mathrm{kgf} / \mathrm{cm}^{2}\right)\end{array}$ \\
Capacity & $230 \mathrm{~mm}(\mathrm{Ram}$ stroke $1230 \mathrm{~mm})$ \\
Stroke & $50 \mathrm{~mm} / \mathrm{sec}(\mathrm{High}), 20 \mathrm{~mm} / \mathrm{sec}(\mathrm{Low})$ \\
Speed & $542 \mathrm{l} / \mathrm{min} \times 210 \mathrm{kgf} / \mathrm{cm}^{2} \times 200 \mathrm{~kW} \times 4 \mathrm{sets}$ \\
Main pump
\end{tabular}

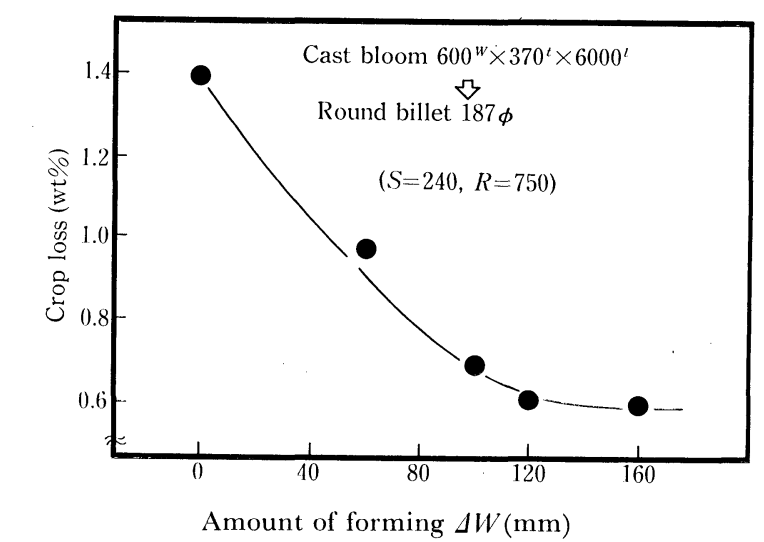

Fig. 2. Decrease in crop loss by press preforming. (Rela-

tionship between amount of forming and crop loss)

Fig. 1. Bloom shape after press preforming.

shape after press preforming and Fig. 2 shows the relationship between amount of forming and crop loss.

In this case the optimum $\Delta W$ is $120 \mathrm{~mm}, S$ is $240 \mathrm{~mm}$ and $R$ is $750 \mathrm{~mm}$.

\section{The Press Facilities}

On basis of these experimental results, a $3000 \mathrm{tf}$ preforming press was developed and installed.

A cast bloom turner and bloom burr removers are additionally installed.

The whole equipment is fully automated.

\section{Result}

This preforming press method improved billet rolling yield by $1.10 \%$, which is about $40 \%$ higher than expected from the experimental results.

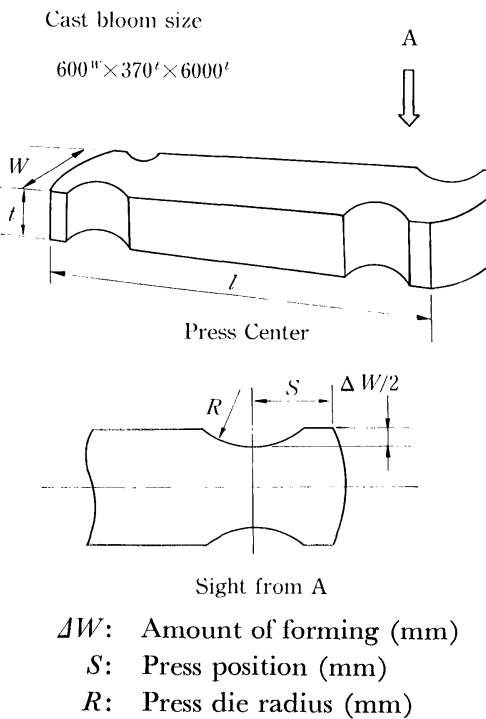

\footnotetext{
* For further information, write to Steelmaking Technical Section, Wakayama Steel Works, Sumitomo Metal Industries, Ltd., 1850, Minato, Wakayama 640. (C) 1986 ISIJ
} 